\title{
Minichromosome maintenance protein 6, a proliferation marker superior to Ki-67 and independent predictor of survival in patients with mantle cell lymphoma
}

\author{
C Schrader, I,2, D Janssen², W Klapper ${ }^{2}$, J-U Siebmann ${ }^{3}$, P Meusers ${ }^{4}$, G Brittinger ${ }^{4}$, M Kneba', M Tiemann ${ }^{2}$ and \\ R Parwaresch ${ }^{2}$
}

'Second Department of Internal Medicine and Hematology, University Hospital of Schleswig-Holstein, Campus Kiel, Chemnitzstr. 33, 24I I6 Kiel, Germany; ${ }^{2}$ Department of Hematopathology and Lymph Node Registry, University Hospital of Schleswig-Holstein, Campus Kiel, Michaelistr. II, 24105 Kiel, Germany; ${ }^{3}$ Department of General Surgery, University Hospital of Schleswig-Holstein, Campus Kiel, Michaelistr. 8, 24 I 05 Kiel, Germany;

${ }^{4}$ Department of Medicine, Division of Hematology, University of Duisburg-Essen, Hufelandstr. 55, 45122 Essen, Germany

Minichromosome maintenance protein 6 (MCM6) is one of six proteins of the MCM family which are involved in the initiation of DNA replication and thus represent a marker of proliferating cells. Since the level of cell proliferation is the most valuable predictor of survival in mantle cell lymphoma (MCL), we investigated lymph node biopsy specimens from 70 patients immunohistochemically with a monoclonal antibody against MCM6. The percentage of MCM6 expressing lymphoma cells ranged from 12.0 to $95.6 \%$, with a mean of $61.0 \%$, and was significantly higher than the percentage of Ki-67-positive cells $(P<0.000 \mathrm{I})$. Surprisingly, the ratio of MCM6-positive cells to Ki-67-positive cells was higher than in normal stimulated peripheral blood mononuclear cells, indicating a cell early GI-phase arrest in MCL. A high MCM6 expression level of more than 75\% positive cells was associated with a significantly shorter overall survival time ( 16 months) compared to MCL with a low MCM6 expression level of less than 25\% (no median reached, $P<0.000 \mathrm{I}$ ). Multivariate analysis revealed MCM6 to be an independent predictor of survival that is superior to the international prognostic factor and the Ki-67 index. Therefore, aside from gene expression profiling, immunohistochemical detection of MCM6 seems to be the most promising marker for predicting the outcome in MCL.

British Journal of Cancer (2005) 93, 939-945. doi:I0.1038/sj.bjc.6602795 www.bjcancer.com

Published online 27 September 2005

(c) 2005 Cancer Research UK

Keywords: mantle cell lymphoma (MCL); proliferation; minichromosome maintenance protein 6 (MCM6); cell cycle; Ki-67

Mantle cell lymphoma (MCL) is a B-cell neoplasm characterised by a typical immunophenotype and the chromosomal translocation $\mathrm{t}(11 ; 14)$ (Tsujimoto et al, 1984; Campo et al, 1999; Bertoni et al, 2004). The clinical course of MCL, although heterogeneous, is usually poor, with a survival time of 3-4 years. For several years a high proliferation rate, as measured by counting the number of mitotic figures or of Ki-67-expressing cells, has been recognised as a marker of poor prognosis (Lardelli et al, 1990; Velders et al, 1996; Raty et al, 2002). However, due to the lack of data from prospective trials and the limited predictive power of the markers available so far, cell proliferation has rarely been used for clinical decisionmaking in MCL. Studies of gene expression profiling demonstrated that a set of genes, designated as the proliferation signature, can predict the clinical outcome of patients with MCL with so far unrivaled precision (Martinez et al, 2003; Rosenwald et al, 2003; Ek et al, 2004). These studies have stimulated the search for new immunohistochemical markers of proliferation that might

* Correspondence: Dr C Schrader, Second Department of Internal Medicine and Hematology, University Hospital of Schleswig-Holstein, Campus Kiel, Chemnitzstr. 33, 24II6 Kiel, Germany;

E-mail: c.schrader@med2.uni-kiel.de

Received 13 April 2005; revised 26 July 2005; accepted 23 August 2005; published online 27 September 2005 take the place of gene expression profiling as a predictor of outcome in MCL.

Minichromosome maintenance (MCM) proteins play an important role in the replication of eukaryotic DNA by binding to chromatin before the initiation of DNA replication (Fujita et al, 1997; Ogawa et al, 1999). Minichromosome maintenance protein 6 (MCM6) is one of six members (MCM2-7) of the MCM family (Lindner et al, 2002) and consists of 821 amino acids with a molecular mass of $105 \mathrm{kDa}$ (Heidebrecht et al, 2001). We have recently developed a specific monoclonal antibody against MCM6 (Ki-MCM6) (Heidebrecht et al, 2001) that enables the accurate detection of MCM6 in paraffin-embedded tissue (Heidebrecht et al, 2001; Helfenstein et al, 2004). Using Ki-MCM6, Heidebrecht et al (2001) showed that MCM6 is detectable in nucleosols or bound to nuclear chromatin during the entire cell cycle G1, S, G2 and $M$ phases, but is absent in G0 phase (Labib et al, 2001). Despite this similar expression pattern of MCM6 and Ki-67 during the cell cycle phases (positive in G1, S, G2 and M phases), detailed cell cycle analysis reveals differences between both markers. During the early G1 phase Ki-67 is undetectable, whereas MCM6 is expressed in the entire G1 phase. Therefore, a small subset of about $20 \%$ of proliferating cells in early G1 phase could be detected by MCM6 and not by Ki-67 in stimulated peripheral blood mononuclear cells (Heidebrecht et al, 2001). 
The clinical relevance of MCM proteins as proliferation markers has been investigated immunohistochemically in several different malignant tumours (Freeman et al, 1999), for example, non-smallcell lung cancer (Ramnath et al, 2001), prostate cancer (Meng et al, 2001; Padmanabhan et al, 2004), oral squamous cell carcinoma (Kodani et al, 2003), chondrosarcoma (Helfenstein et al, 2004), oligodendroglial tumours (Wharton et al, 2001, 2004), oesophageal neoplasm (Going et al, 2002), renal cell carcinoma (Dudderidge et al, 2005), breast cancer (Gonzalez et al, 2004), endometrial carcinoma (Li et al, 2005) and thyroid carcinoma (Guida et al, 2005). Most of these studies focused on the detection of MCM2 (Freeman et al, 1999; Chatrath et al, 2003; Davidson et al, 2003; Kodani et al, 2003; Scott et al, 2004). So far only few investigations studied MCM6 expression (Labib et al, 2001; Helfenstein et al, 2004).

The MCM2 expression was also analysed in 36 patients with malignant B-cell lymphomas, including 11 cases with MCL (Obermann et al, 2005). The authors included also Ki-67 and geminin (Lygerou and Nurse, 2000; Wohlschlegel et al, 2000; Madine and Laskey, 2001) in their study and could demonstrate that low-grade lymphomas reside in an 'in-cycle' G1 state and not in G0. In this very important study of Obermann et al (2005), the authors did not analyse the MCM2 expression in relation to clinical data.

The aim of this study was to investigate MCM as a new proliferation marker in a large group of patients with MCL and to correlate the results with established prognostic factors for this disease. Since we have developed an antibody that accurately identifies MCM6 in paraffin-embedded tissues, an expression pattern that was tested in normal peripheral blood mononuclear cells (Heidebrecht et al, 2001), we chose this antibody to determine MCM protein expression in this lymphoma.

\section{PATIENTS AND METHODS}

Biopsy specimens (lymph nodes only) from 70 previously untreated patients (Table 1) from two trials (1975 and 1985) (Brittinger et al, 1984; Meusers et al, 1989) were recut and stained with haematoxylin and eosin, Giemsa and Gomori silver impregnation. The cytology was classified according to the WHO classification of MCL into classical and blastoid subtypes (Jaffe et al, 2001). The diagnosis of MCL was verified by two reference pathologists from the European Mantle Cell Lymphoma Network (MT and RP).

\section{Antibodies and immunohistochemical staining}

The immunohistochemical investigation was performed as described previously (Schrader et al, 2004). All sections were stained with antibodies against CD3 (dilution 1:20) (DAKO, Hamburg, Germany), CD5 (dilution $1: 25$ ) (Novocastra, Newcastle, UK), CD20 (dilution 1:5) (DAKO), CD23 (dilution 1:20) (Novocastra),

Table I Univariate analysis of prognostic factors in relation to MCM6 expression

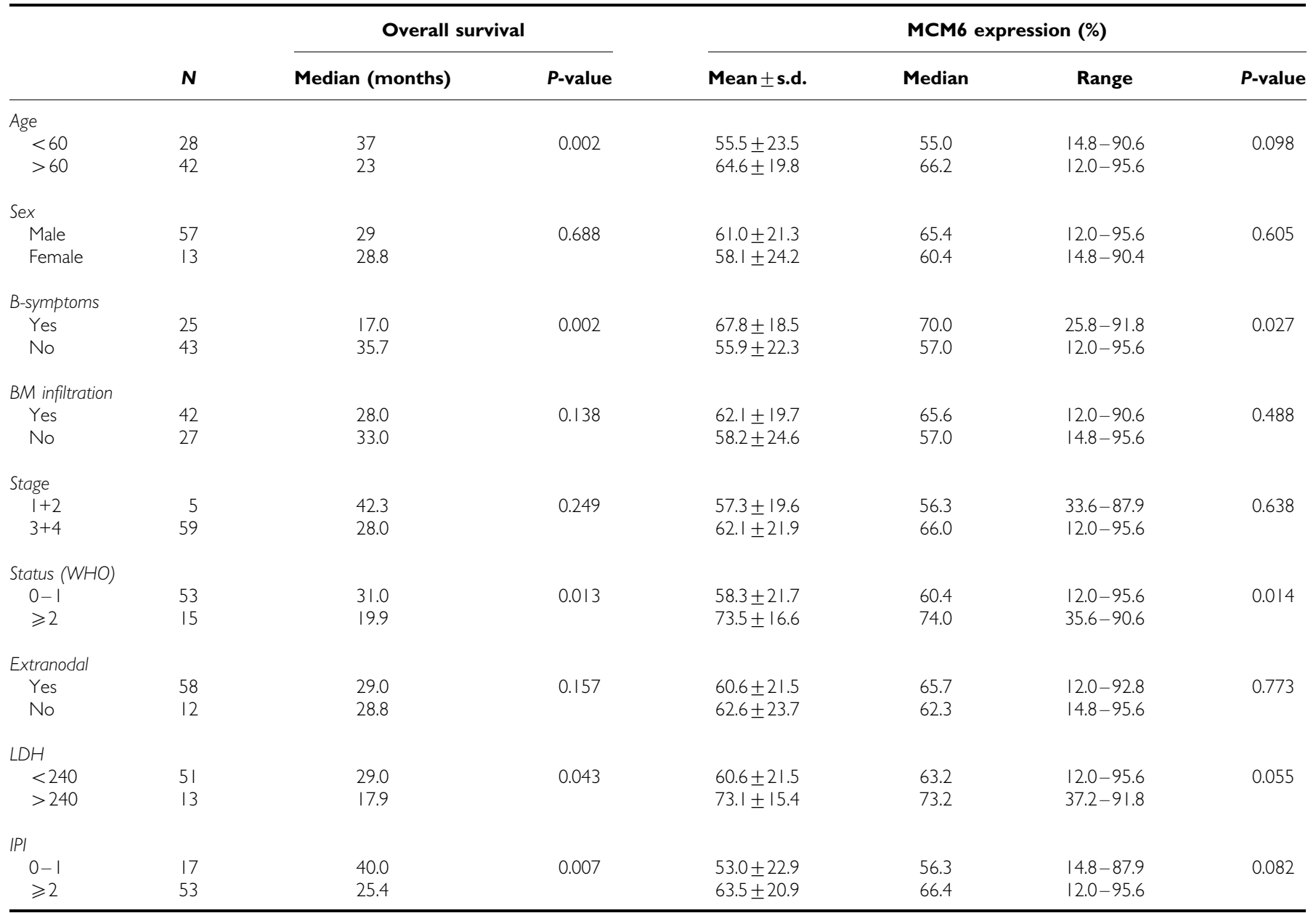

$\mathrm{BM}=$ bone marrow; stage = Ann Arbor stage; status = performance status; extranodal = extranodal involvement; LDH = lactate dehydrogenase; IPI = International Prognostic Index; full data are not availble for all patients. 
cyclin-D1 (dilution $1: 20$ ) (Novocastra), MCM6 (dilution $1: 1$, cell culture supernatant) (Ki-MCM6, Department of Hematopathology, University of Kiel, Germany) and anti-Ki-67 (dilution 1:1, cell culture supernatant) (Ki-S5, Department of Hematopathology, University of Kiel, Germany). The stainings were evaluated by investigators blinded to the clinical information. In each stained section 500 neoplastic cells were counted. The MCM6 index was calculated as the percentage of positive nuclei. Only nuclear staining was counted as MCM6 positive.

Tonsil tissue was used as positive controls; negative control samples were incubated with serum instead of the primary antibody.

\section{Statistical methods}

For the statistical tests SPSS (SPSS Inc., version 11, Chicago, IL, USA) was used. Various parameters were analysed statistically by two-sided $t$-test and the correlation coefficient, as indicated. Overall survival analysis (univariate) was analysed by the KaplanMeier method. Differences in significance $(P \leqslant 0.05)$ were assessed by means of the log-rank test. All clinical parameters were also compared by means of a multivariate Cox regression analysis using a stepwise (forward and backward) conditional approach.

\section{RESULTS}

In 57 cases of MCL (81.4\%) cytological analysis revealed a classical cytology and in 13 cases (18.6\%) a blastoid cytological subtype. Immunophenotyping showed coexpression of CD20 and CD5 in all cases and negativity of the tumour cells for CD23. Cyclin D1 staining was positive in 69 cases $(98.6 \%)$. In one case $(1.4 \%)$ cyclin D1 staining could not be evaluated for technical reasons.

Minichromosome maintenance protein 6 staining was restricted to the cell nucleus. The expression level ranged from 12.0 to $95.6 \%$, with a median of $64.6 \%$ and a mean of $61.0 \%$ (Figures $1 \mathrm{~A}$ and $\mathrm{B}$ ). We retrieved data on Ki-67 expression from our previous investigation on the same collection of samples (Schrader et al, 2004). As expected, the MCM6 index was significantly higher than the Ki-67 index (Figure 2, $P<0.0001$ ), with a mean for Ki-67 of $19.8 \%$, compared to $61.0 \%$ for MCM6. Also not unexpectedly, the two markers showed a significant correlation (Figure 3, $P<0.0001)$. Surprisingly, cytological variants like the blastoid variant did not differ in their MCM6 expression level $(P=0.2672)$. In contrast, in our previous and other studies (Lardelli et al, 1990; Ott et al, 1997; Campo et al, 1999), the Ki-67 index was significantly higher in blastoid variants than in cases with classical cytology. By calculating the ratio of MCM6 and Ki-67, the majority of cases had high indices (mean: $4.7 \pm 4.6$ ).

Univariate analysis of MCM6 expression in relation to clinical characteristics revealed no significant differences concerning age, sex, stage of the disease, bone marrow infiltration, extranodal involvement, lactate dehydrogenase level and IPI score (Table 1). The only significant differences concerned B-symptoms and WHO status (Table 1). A multivariate analysis of 52 patients with complete data for all variables showed that only MCM6 expression $(P<0.0001)$ and IPI $(P=0.0018)$ were prognostic factors for the clinical outcome (Table 2) in our group of patients.

The patients were ranked according to their MCM6 expression level and divided into four equal quartiles (Table 3). Figure 4 shows the Kaplan-Meier analysis of overall survival time for patients in different quartiles. These data indicate that the MCM expression can identify patients with a good and a poor prognosis. The median survival times for the quartiles are listed in Table 3. In accordance with Ramnath et al (2001), we analysed the MCM expression in four categories. Patients with an MCM6 expression level of lower than $25 \%$ had not yet reached a median survival, in contrast to 38.2 months for the group with $25-50 \%, 30$ months for

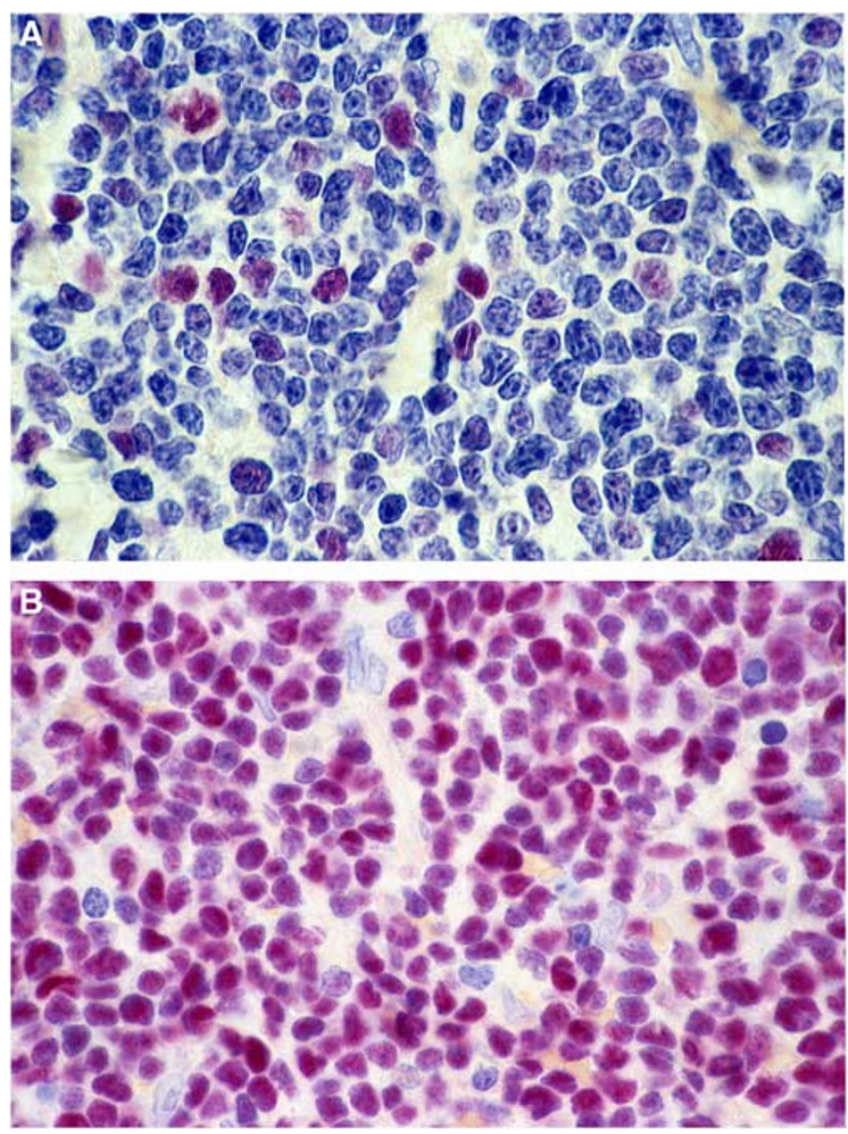

Figure I (A) Mantle cell lymphoma with a low level of MCM6 expression $(<25 \%)$. APAAP staining, magnification $\times 1000$. (B) Very high MCM6 expression (>75\%). APAAP staining, magnification $\times 1000$.

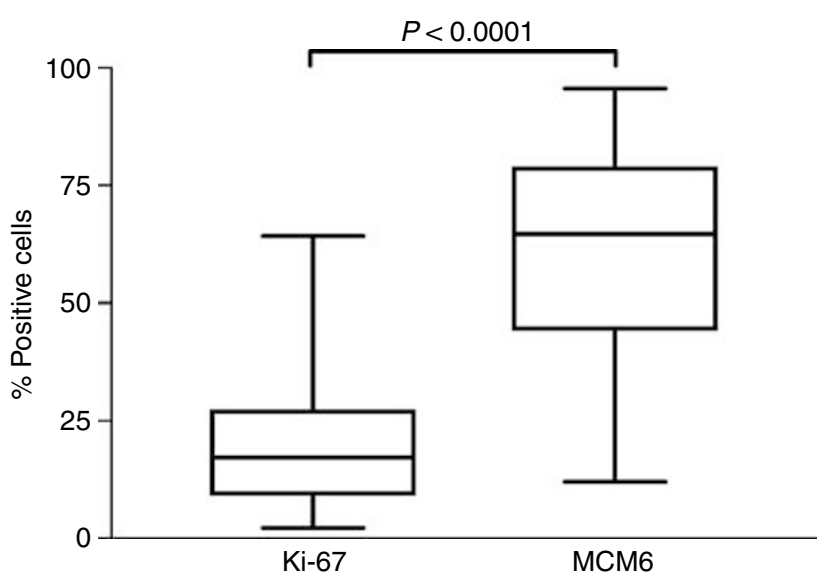

Figure 2 Minichromosome maintenance protein 6 and Ki-67 expression as \% positive cells in all cases.

the group with $50-75 \%$ and 16.0 months for patients with more than $75 \%$ (Figure 5 and Table $3, P<0.0001$ ).

\section{DISCUSSION}

Minichromosome maintenance proteins are components of the prereplicative complex and are essential for the initiation of DNA replication (Labib et al, 2001). With the development of 
monoclonal antibodies against MCM proteins, their use as proliferation markers for the analysis of archived tissue has become possible. To date, most studies have focused on MCM2 expression, for example, in oral squamous cell carcinomas (Kodani et al, 2003), prostate cancer (Meng et al, 2001; Padmanabhan et al, 2004) and ovarian serous neoplasms (Scott et al, 2004) chondrosarcoma (Helfenstein et al, 2004), oligodendroglial tumours (Wharton et al, 2001, 2004), oesophageal neoplasm (Going et al, 2002), renal cell carcinoma (Dudderidge et al, 2005), breast cancer (Gonzalez et al, 2004), endometrial carcinoma (Li et al, 2005) and thyroid carcinoma (Guida et al, 2005).

In a large study, Ramnath et al (2001) examined 221 patients with lung cell cancer immunohistochemically for MCM2 expression and found MCM2 expression to be an independent prognostic factor for survival. In this study, patients with MCM2 expression in less than $25 \%$ of the tumour cells had a significantly better prognosis than patients with tumours with a higher MCM2 index. Additional to the study by Ramnath, only few studies have investigated MCM proteins immunohistochemically. Brake et al (2003) focused on MCM7 in cervical cancer and Helfenstein et al (2004) on MCM6 in chondrosarcoma using the monoclonal antibody Ki-MCM6, also employed in our study.

The MCM expression in peripheral B-cell lymphomas was investigated for the first time by Obermann et al (2005), who could demonstrate that also in MCLs the majority of lymphoma cells reside in the cell cycle phases G1, but not in S/G2/M. These data are in line with our results of repp86 in a large series of 94 patients with MCL (Schrader et al, 2005). Repp86 is a spindle apparatusassociated protein expressed only during S/G2/M, absent in G1 and

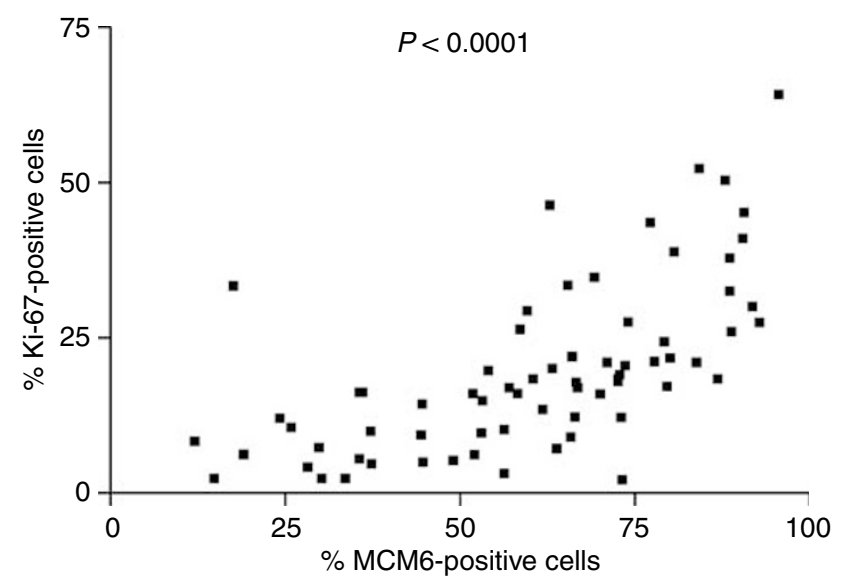

Figure 3 Correlation analysis of MCM6 and Ki-67 expression.
G0, and thus displaying the same cell cycle expression pattern like geminin (Heidebrecht et al, 1997, 2003; Lygerou and Nurse, 2000; Wohlschlegel et al, 2000; Madine and Laskey, 2001; Hodgson et al, 2002). We could demonstrate that the majority of the 94 cases have lower repp86 expression than Ki-67, and this indicates a G1 arrest in the subset of cases in our collective.

Mantle cell lymphomas are mature B-cell neoplasms with a poor prognosis. Measures to predict the heterogeneous clinical outcome

Table 3 Results of the analysis of MCM6 expression in relation to the overall survival time in 70 patients with $\mathrm{MCL}$

\begin{tabular}{lcccc}
\hline MCM6 expression & $\boldsymbol{n}(\%)$ & $\begin{array}{c}\text { Median OS } \\
\text { (months) }\end{array}$ & $\begin{array}{c}\text { 5-year } \\
\text { survival (\%) }\end{array}$ & P-value \\
\hline $\begin{array}{l}\text { Quartile 1 } \\
\text { 12.0-44.7\% }\end{array}$ & $18(25.7)$ & 40.0 & 22.2 & $<0.0001$ \\
$\begin{array}{l}\text { Quartile 2 } \\
\text { 49.0-65.4\% }\end{array}$ & $18(25.7)$ & 36.0 & 11.1 & \\
$\begin{array}{l}\text { Quartile 3 } \\
\text { 65.8-77.8\% }\end{array}$ & $17(24.3)$ & 25.4 & 0 & \\
Quartile 4 & $17(24.3)$ & 17.5 & 0 & \\
$79.2-95.6 \%$ & & & & \\
& & & & \\
$0-25 \%$ & $5(7.1)$ & Not reached & 60.0 & $<0.0001$ \\
$>25-50 \%$ & $14(20.0)$ & 38.2 & 14.3 & \\
$>50-75 \%$ & $32(45.7)$ & 30.0 & 6.3 & \\
$>75-100 \%$ & $19(27.1)$ & 16.0 & 0 & \\
\hline
\end{tabular}

OS = overall survival time.
Table 2 Uni- and multivariate Cox regression analysis of all prognostic factors with respect to overall survival in 52 MCL patients with complete data available (out of 70 patients)

\begin{tabular}{|c|c|c|c|}
\hline \multirow[b]{2}{*}{ Characteristics } & \multirow[b]{2}{*}{ Reference level } & \multicolumn{2}{|c|}{$P$-value } \\
\hline & & Univariate & Multivariate \\
\hline MCM6 expression & $0-25 \%$ vs $>25-50 \%$ vs $>50-75 \%$ vs $>75 \%$ & $<0.0001$ & $<0.0001$ \\
\hline Ki-67 expression & $\leqslant 10 \%$ vs $>10 \%$ & 0.0045 & 0.2473 \\
\hline International prognostic index & $0-1$ vs $\geqslant 2$ & 0.0011 & 0.0018 \\
\hline $\mathrm{LDH}$ & Normal vs elevated & 0.0841 & 0.7638 \\
\hline Age & $<60$ vs $>60$ & 0.0083 & 0.5001 \\
\hline Sex & Male vs female & 0.6679 & 0.8449 \\
\hline B-symptoms & Yes vs no & 0.0241 & 0.4884 \\
\hline Bone marrow infiltration & Yes vs no & 0.0650 & 0.9970 \\
\hline Stage & $1+2$ vs $3+4$ & 0.6677 & 0.7943 \\
\hline Performance status $(\mathrm{WHO})$ & $0+1 v s \geqslant 2$ & 0.0246 & 0.4430 \\
\hline Extranodal involvement & Yes vs no & 0.0749 & 0.3797 \\
\hline
\end{tabular}




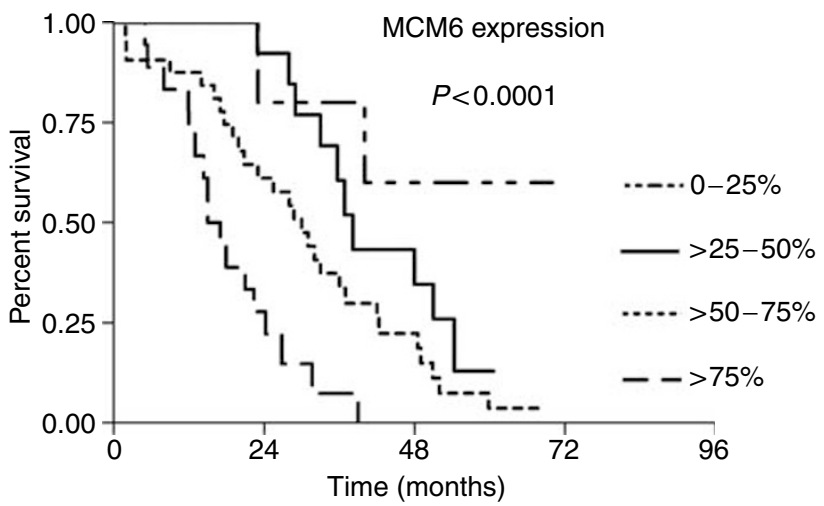

Figure 5 Kaplan-Meier analysis of overall survival time of patients with MCL and different MCM6 expression levels.

of the disease are needed to guide clinical decision-making. Studies of gene expression profiling in MCL have stressed the importance of cell proliferation for the clinical outcome. Rosenwald et al (2003) summarised predictive genes for survival as the 'proliferation signature' since most of these genes are thought to be involved in cell cycle progression, mitosis or DNA replication. Data from gene expression profiling experiments are describing transcriptional changes of mRNA and cannot be necessarily be translated into protein expression. Furthermore, due to the high costs and technical obstacles like the need for fresh material, gene expression profiling is limited in its use for routine analysis of tumour samples. For these reasons, it is useful to confirm results based on gene expression profiling on the protein level with, for example, by immunohistochemistry. In a previous study, we studied topoisomerase II $\alpha$ expression by immunohistochemistry and were able to confirm the results from Rosenwald et al (Schrader et al, 2004). Since mRNA expression of MCM2, was reported to be associated with bad prognosis (Rosenwald et al, 2003), we evaluated MCM protein expression by immunohistochemistry in MCL. Out of the family of MCM proteins we chose MCM6 for our analysis, because a highly reliable monoclonal antibody against this MCM family member was available (Heidebrecht et al, 2001).

First we ranked the patients according to their MCM6 expression level and divided into four equal groups (quartiles). Kaplan-Meier analysis showed significant differences in the overall survival time in different quartiles (Figure 4, Table 3, $P<0.0001)$. Second, for the Kaplan-Meier analysis, we chose different MCM6 expression levels according to the categories of Ramnath et al (2001). In the group under 25\% MCM6-positive cells, the median overall survival time was despite the long followup time not reached, indicating that this group of patients has an excellent prognosis. The other patients with higher MCM6 expression had a significantly shorter overall survival, with a median of 38.2 months in the group $>25-50 \%$ positive cells compared to the group representing $>50-75 \%$ MCM6-positive cells, which had a median of 30.0 months. The highly proliferating group of $75 \%$ and more MCM6-positive cells had a median survival time of only 16 months $(P<0.0001)$. In the multivariate Cox regression analysis which included Ki-67, only MCM6 expression $(P<0.0001)$ and IPI score $(P=0.0018)$ proved to be prognostic factors for clinical outcome of patients with MCL. These results clearly indicate that MCM6 expression is a much stronger predictor of overall survival in MCL than Ki-67. Further, the data confirm the data from gene expression profiling studies that MCM protein expression can predict overall survival in MCL. It will be interesting to evaluate if MCM2 expression by immunohistochemistry is as effective as MCM6 expression reported here.

Minichromosome maintenance protein 6 expression in MCL ranged from 12.0 to $95.6 \%$, with a mean of $60.9 \%$. In contrast, the Ki-67 index was significantly lower, with a mean of $19.8 \%$ and a range between 2.2 and $64.2 \%$. Nevertheless, the Ki-67 and MCM6 indices showed a good correlation (Figure 3, $P<0.0001$ ). These data are in line with others (Ramnath et al, 2001; Helfenstein et al, 2004), indicating that the ratio of MCM6- and Ki-67-positive cells is larger in MCL than the Ki-67 expressing cells. Blastoid variants usually have a more aggressive clinical behaviour than classical types, and the proliferation indices in the blastoid subtypes are usually higher (Schrader et al, 2004). To our surprise, there were no significant differences in MCM6 expression $(P=0.27)$ between the different cytological subtypes. Although both markers MCM6 and Ki-67 are expressed in the G1, S, G2 and $\mathrm{M}$ phases of the cell cycle, the higher number of MCM6-positive cells can be explained by the expression of MCM6 in the early G1 phase, when Ki-67 expression cannot be detected (Heidebrecht et al, 2001). Compared to stimulated peripheral blood mononuclear cells (ratio: mean: $1.4 \pm 0.5$; Heidebrecht et al, 2001), the difference between Ki-67 and MCM6 positive cells in our series of MCLs is higher (mean: $4.7 \pm 4.6$ ). These data show that a subset of mantle cell tumour cells is arrested in the early G1 phase and the MCM6-positive cells do not necessarily represent the real proliferating compartment of the lymphoma. This fact could also explain why the blastoid and classical subtype had no significant difference in the MCM6 expression as a marker for the G1 arrest and not as a proliferation marker. As this cell cycle arrest has been shown by others (Stoeber et al, 2001; Eward et al, 2004; Obermann et al, 2005; Tachibana et al, 2005), we could demonstrate that this has a clinical relevance in patients with MCLs. Our data on expression of repp86 in MCL (Schrader et al, 2005) showed that real proliferation activity is an important prognostic factor in MCL. On the other hand, patients with cell arrest (G1 arrest) indicated by high MCM6 expression also predict survival in this disease.

The typical translocation $\mathrm{t}(11 ; 14)(\mathrm{q} 13 ; \mathrm{q} 32)$ of MCLs causes an overexpression of the cell cycle regulating protein cyclin $\mathrm{D} 1$, that binds to the cyclin-depending kinases (CDK) 4 and 6 and therefore plays an important role in the control of the G1 phase in the cell cycle (Hunter and Pines, 1994). The cyclin/CDK complexes are important for progression of cells into $S$ phase. Taking this molecular mechanism in consideration, it is more surprising that a majority of MCL tumour cells are not in S-M-G2 phases, but in G1 arrest. Future research has to combine markers of cell proliferation and cell cycle arrest with markers of other biological processes like apoptosis (Martinez et al, 2003) to get insight into the biology and explain the heterogeneous therapeutic response of this disease.

In conclusion, high MCM6 expression indicates early G1-phase arrest, and is a new prognostic marker in MCL superior to other clinical prognostic parameters and Ki-67 expression.

\section{REFERENCES}

Bertoni F, Zucca E, Cavalli F (2004) Mantle cell lymphoma. Curr Opin Hematol 11: $411-418$

Brake T, Connor JP, Petereit DG, Lambert PF (2003) Comparative analysis of cervical cancer in women and in a human papillomavirus-transgenic mouse model: identification of minichromosome maintenance protein 7 as an informative biomarker for human cervical cancer. Cancer Res 63: 8173-8180 Brittinger G, Bartels H, Common H, Duhmke E, Fulle HH, Gunzer U, Gyenes T, Heinz R, Konig E, Meusers P (1984) Clinical and prognostic 
relevance of the Kiel classification of non-Hodgkin lymphomas. Results of a prospective multicenter study by the Kiel Lymphoma Study Group. Hematol Oncol 2: 269-306

Campo E, Raffeld M, Jaffe ES (1999) Mantle-cell lymphoma. Semin Hematol 36: $115-127$

Chatrath P, Scott IS, Morris LS, Davies RJ, Rushbrook SM, Bird K, Vowler SL, Grant JW, Saeed IT, Howard D, Laskey RA, Coleman N (2003) Aberrant expression of minichromosome maintenance protein-2 and Ki67 in laryngeal squamous epithelial lesions. Br J Cancer 89: 1048-1054

Davidson EJ, Morris LS, Scott IS, Rushbrook SM, Bird K, Laskey RA, Wilson GE, Kitchener HC, Coleman N, Stern PL (2003) Minichromosome maintenance $(\mathrm{Mcm})$ proteins, cyclin $\mathrm{B} 1$ and $\mathrm{D} 1$, phosphohistone $\mathrm{H} 3$ and in situ DNA replication for functional analysis of vulval intraepithelial neoplasia. Br J Cancer 88: 257-262

Dudderidge TJ, Stoeber K, Loddo M, Atkinson G, Fanshawe T, Griffiths DF, Williams GH (2005) Mcm2, Geminin, and KI67 define proliferative state and are prognostic markers in renal cell carcinoma. Clin Cancer Res 11: $2510-2517$

Ek S, Bjorck E, Porwit-MacDonald A, Nordenskjold M, Borrebaeck CA (2004) Increased expression of Ki-67 in mantle cell lymphoma is associated with de-regulation of several cell cycle regulatory components, as identified by global gene expression analysis. Haematologica 89: 686-695

Eward KL, Obermann EC, Shreeram S, Loddo M, Fanshawe T, Williams C, Jung HI, Prevost AT, Blow JJ, Stoeber K, Williams GH (2004) DNA replication licensing in somatic and germ cells. J Cell Sci 117: 5875-5886

Freeman A, Morris LS, Mills AD, Stoeber K, Laskey RA, Williams GH, Coleman N (1999) Minichromosome maintenance proteins as biological markers of dysplasia and malignancy. Clin Cancer Res 5: 2121-2132

Fujita M, Kiyono T, Hayashi Y, Ishibashi M (1997) In vivo interaction of human MCM heterohexameric complexes with chromatin. Possible involvement of ATP. J Biol Chem 272: 10928-10935

Going JJ, Keith WN, Neilson L, Stoeber K, Stuart RC, Williams GH (2002) Aberrant expression of minichromosome maintenance proteins 2 and 5 , and Ki-67 in dysplastic squamous oesophageal epithelium and Barrett's mucosa. Gut 50: 373-377

Gonzalez MA, Tachibana KE, Chin SF, Callagy G, Madine MA, Vowler SL, Pinder SE, Laskey RA, Coleman N (2004) Geminin predicts adverse clinical outcome in breast cancer by reflecting cell-cycle progression. J Pathol 204: 121 - 130

Guida T, Salvatore G, Faviana P, Giannini R, Garcia-Rostan G, Provitera L, Basolo F, Fusco A, Carlomagno F, Santoro M (2005) Mitogenic effects of the up-regulation of minichromosome maintenance (MCM) proteins in anaplastic thyroid carcinoma. J Clin Endocrinol Metab 190: 4703-4709

Heidebrecht HJ, Adam-Klages S, Szczepanowski M, Pollmann M, Buck F, Endl E, Kruse ML, Rudolph P, Parwaresch R (2003) repp86: a human protein associated in the progression of mitosis. Mol Cancer Res 1: $271-279$

Heidebrecht HJ, Buck F, Endl E, Kruse ML, Adam-Klages S, Andersen K, Frahm SO, Schulte C, Wacker HH, Parwaresch R (2001) Ki-Mcm6, a new monoclonal antibody specific to Mcm6: comparison of the distribution profile of Mcm6 and the Ki-67 antigen. Lab Invest 81: 1163-1165

Heidebrecht HJ, Buck F, Steinmann J, Sprenger R, Wacker HH, Parwaresch $\mathrm{R}$ (1997) p100: a novel proliferation-associated nuclear protein specifically restricted to cell cycle phases S, G2, and M. Blood 90: $226-233$

Helfenstein A, Frahm SO, Krams M, Drescher W, Parwaresch R, Hassenpflug J (2004) Minichromosome maintenance protein (MCM6) in low-grade chondrosarcoma: distinction from enchondroma and identification of progressive tumors. Am J Clin Pathol 122: 912-918

Hodgson B, Li A, Tada S, Blow JJ (2002) Geminin becomes activated as an inhibitor of Cdt1/RLF-B following nuclear import. Curr Biol 12: 678-683

Hunter T, Pines J (1994) Cyclins and cancer. II: Cyclin D and CDK inhibitors come of age. Cell 79: $573-582$

Jaffe ES, Harris NL, Stein H, Vardiman JW (2001) World Health Organization Classification of Tumours. Pathology and Genetics of Tumours of Haematopoietic and Lymphoid Tissues. Lyon: IARC Press

Kodani I, Osaki M, Shomori K, Araki K, Goto E, Ryoke K, Ito H (2003) Minichromosome maintenance 2 expression is correlated with mode of invasion and prognosis in oral squamous cell carcinomas. J Oral Pathol Med 32: $468-474$

Labib K, Kearsey SE, Diffley JF (2001) MCM2-7 proteins are essential components of prereplicative complexes that accumulate cooperatively in the nucleus during G1-phase and are required to establish, but not maintain, the S-phase checkpoint. Mol Biol Cell 12: 3658-3667
Lardelli P, Bookman MA, Sundeen J, Longo DL, Jaffe ES (1990) Lymphocytic lymphoma of intermediate differentiation. Morphologic and immunophenotypic spectrum and clinical correlations. Am J Surg Pathol 14: $752-763$

Li SS, Xue WC, Khoo US, Ngan HY, Chan KY, Tam IY, Chiu PM, Ip PP, Tam KF, Cheung AN (2005) Replicative MCM7 protein as a proliferation marker in endometrial carcinoma: a tissue microarray and clinicopathological analysis. Histopathology 46: 307-313

Lindner K, Gregan J, Montgomery S, Kearsey SE (2002) Essential role of MCM proteins in premeiotic DNA replication. Mol Biol Cell 13: 435-444

Lygerou Z, Nurse P (2000) Cell cycle. License withheld - geminin blocks DNA replication. Science 290: 2271-2273

Madine M, Laskey R (2001) Geminin bans replication licence. Nat Cell Biol 3: E49-E50

Martinez N, Camacho FI, Algara P, Rodriguez A, Dopazo A, Ruiz-Ballesteros E, Martin P, Martinez-Climent JA, Garcia-Conde J, Menarguez J, Solano F, Mollejo M, Piris MA (2003) The molecular signature of mantle cell lymphoma reveals multiple signals favoring cell survival. Cancer Res 63: 8226-8232

Meng MV, Grossfeld GD, Williams GH, Dilworth S, Stoeber K, Mulley TW, Weinberg V, Carroll PR, Tlsty TD (2001) Minichromosome maintenance protein 2 expression in prostate: characterization and association with outcome after therapy for cancer. Clin Cancer Res 7: 2712-2718

Meusers P, Engelhard M, Bartels H, Binder T, Fulle HH, Gorg K, Gunzer U, Havemann K, Kayser W, Konig E (1989) Multicentre randomized therapeutic trial for advanced centrocytic lymphoma: anthracycline does not improve the prognosis. Hematol Oncol 7: 365-380

Obermann EC, Eward KL, Dogan A, Paul EA, Loddo M, Munson P, Williams GH, Stoeber K (2005) DNA replication licensing in peripheral B-cell lymphoma. J Pathol 205: 318-328

Ogawa Y, Takahashi T, Masukata H (1999) Association of fission yeast Orp1 and Mcm6 proteins with chromosomal replication origins. Mol Cell Biol 19: $7228-7236$

Ott G, Kalla J, Ott MM, Schryen B, Katzenberger T, Muller JG, MullerHermelink HK (1997) Blastoid variants of mantle cell lymphoma: frequent bcl-1 rearrangements at the major translocation cluster region and tetraploid chromosome clones. Blood 89: 1421-1429

Padmanabhan V, Callas P, Philips G, Trainer TD, Beatty BG (2004) DNA replication regulation protein $\mathrm{Mcm} 7$ as a marker of proliferation in prostate cancer. J Clin Pathol 57: 1057-1062

Ramnath N, Hernandez FJ, Tan DF, Huberman JA, Natarajan N, Beck AF, Hyland A, Todorov IT, Brooks JS, Bepler G (2001) MCM2 is an independent predictor of survival in patients with non-small-cell lung cancer. J Clin Oncol 19: 4259-4266

Raty R, Franssila K, Joensuu H, Teerenhovi L, Elonen E (2002) Ki-67 expression level, histological subtype, and the International Prognostic Index as outcome predictors in mantle cell lymphoma. Eur J Haematol 69: $11-20$

Rosenwald A, Wright G, Wiestner A, Chan WC, Connors JM, Campo E, Gascoyne RD, Grogan TM, Muller-Hermelink HK, Smeland EB, Chiorazzi M, Giltnane JM, Hurt EM, Zhao H, Averett L, Henrickson S, Yang L, Powell J, Wilson WH, Jaffe ES, Simon R, Klausner RD, Montserrat E, Bosch F, Greiner TC, Weisenburger DD, Sanger WG, Dave BJ, Lynch JC, Vose J, Armitage JO, Fisher RI, Miller TP, LeBlanc M, Ott G, Kvaloy S, Holte H, Delabie J, Staudt LM (2003) The proliferation gene expression signature is a quantitative integrator of oncogenic events that predicts survival in mantle cell lymphoma. Cancer Cell 3: 185-197

Schrader C, Janssen D, Meusers P, Brittinger G, Siebmann JU, Parwaresch R, Tiemann M (2005) Repp86: a new prognostic marker in mantle cell lymphoma. Eur J Haematol, in press

Schrader C, Meusers P, Brittinger G, Teymoortash A, Siebmann JU, Janssen D, Parwaresch R, Tiemann M (2004) Topoisomerase IIalpha expression in mantle cell lymphoma: a marker of cell proliferation and a prognostic factor for clinical outcome. Leukemia 18: 1200-1206

Scott IS, Heath TM, Morris LS, Rushbrook SM, Bird K, Vowler SL, Arends MJ, Coleman N (2004) A novel immunohistochemical method for estimating cell cycle phase distribution in ovarian serous neoplasms: implications for the histopathological assessment of paraffin-embedded specimens. Br J Cancer 90: 1583-1590

Stoeber K, Tlsty TD, Happerfield L, Thomas GA, Romanov S, Bobrow L, Williams ED, Williams GH (2001) DNA replication licensing and human cell proliferation. J Cell Sci 114: 2027-2041

Tachibana KE, Gonzalez MA, Coleman N (2005) Cell-cycle-dependent regulation of DNA replication and its relevance to cancer pathology. J Pathol 205: $123-129$ 
Tsujimoto Y, Yunis J, Onorato-Showe L, Erikson J, Nowell PC, Croce CM (1984) Molecular cloning of the chromosomal breakpoint of B-cell lymphomas and leukemias with the $\mathrm{t}(11 ; 14)$ chromosome translocation. Science 224: $1403-1406$

Velders GA, Kluin-Nelemans JC, de BC, Hermans J, Noordijk EM, Schuuring E, Kramer MH, Van DW, Rahder JB, Kluin PM, van KJ (1996) Mantle-cell lymphoma: a population-based clinical study. J Clin Oncol 14: 1269 - 1274

Wharton SB, Chan KK, Anderson JR, Stoeber K, Williams GH (2001) Replicative $\mathrm{Mcm} 2$ protein as a novel proliferation marker in oligodendrogliomas and its relationship to Ki67 labelling index, histological grade and prognosis. Neuropathol Appl Neurobiol 27: $305-313$

Wharton SB, Hibberd S, Eward KL, Crimmins D, Jellinek DA, Levy D, Stoeber K, Williams GH (2004) DNA replication licensing and cell cycle kinetics of oligodendroglial tumours. $\mathrm{Br} J$ Cancer 91: $262-269$

Wohlschlegel JA, Dwyer BT, Dhar SK, Cvetic C, Walter JC, Dutta A (2000) Inhibition of eukaryotic DNA replication by geminin binding to Cdt1. Science 290: 2309-2312 